\title{
IbM: PEMANFAATAN LIMBAH PLASTIK SEBAGAI KERAJINAN TANGAN DI KELURAHAN SRENGSENG SAWAH JAGAKARSA JAKARTA SELATAN
}

\author{
Siti Rohana Nasution ${ }^{1)}$, Dwi Rahmalina ${ }^{1)}$, Bambang Sulaksono ${ }^{1)}$ dan Carla Olyvia Doaly ${ }^{2)}$ \\ ${ }^{1)}$ Fakultas Teknik Universitas Pancasila \\ ${ }^{2)}$ Program Studi Teknik Industri Universitas Tarumanagara \\ e-mail: siti_rohana@univpancasila.ac.id
}

\begin{abstract}
ABSTRAK
Permasalahan sampah menjadi problema klasik yang selalu dihadapi oleh penduduk terutama di wilayah Srengseng Sawah Jagakarsa. Karena kuantitas maupun tingkat bahayanya, sampah terutama sampah plastik yang tersusun dari bahan kimia sukar diuraikan sehingga berbahaya bagi lingkungan, untuk itu perlu dilakukan pengolahan sampah untuk mengubah sampah plastik menjadi kerajinan yang memiliki nilai jual dan estetika. Metode yang digunakan dalam program pemanfaatan limbah plastik sebagai kerajian adalah survey analisis situasi dan pelaksanaan penyuluhan dan pelatihan. Implemetasi hasil proses pengolahan sampah yang berasal dari kemasan plastik menjadi kerajinan tangan di Kelurahan Srengseng Sawah dilakukan untuk meningkatkan kreatifitas serta keterampilan warga terutama ibu-ibu rumah tangga, pemuda pengangguran dan anak-anak yang putus sekolah. Selain itu juga dapat meminimalisir pencemaran lingkungan sehingga warga Kelurahan Srengseng Sawah dapat lebih peduli terhadap kebersihan lingkungan. Melalui pelatihan dan pendampingan pembuatan kreasi pemanfaatan sampah yang berasal dari kemasan plastik warga lebih punya pengetahuan mengenai peluang usaha yang dapat tercipta melalui kreatifitas dan keterampilan tersebut agar tingkat ekonomi warga Kelurahan Srengseng Sawah menjadi lebih tinggi.
\end{abstract}

Kata Kunci: Reuse, Recycle, Reduse.

\begin{abstract}
The problem of garbage is a classic problem that is always faced by the population, especially in Srengseng sawah Jagakarsa region. Because of the quantity and the level of danger, waste, especially plastic waste which is composed of chemicals, is difficult to decipher so that it is dangerous for the environment, so it is necessary to process waste to convert plastic waste into crafts that have a sale value and aesthetics. The method used in the plastic waste utilization program as a study is a situation analysis survey and implementation of counseling and training. Implication of the results of the processing of waste from plastic packaging into handicrafts in Srengseng Sawah Village is done to increase the creativity and skills of residents, especially housewives, unemployed youth and school dropouts. In addition, it can also minimize environmental pollution so that residents of Srengseng Sawah Village can be more concerned about environmental cleanliness. Through training and mentoring, the creation of waste utilization from plastic packaging residents has more knowledge about business opportunities that can be created through creativity and skills so that the economic level of Srengseng Sawah Village residents is higher.
\end{abstract}

Keywords: Reuse, Recycle, Reduse.

\section{PENDAHULUAN}

Dewasa ini, sampah menjadi salah satu permasalahan yang cukup sulit di tangani di Indonesia. Hal ini terjadi karena kebiasaan masyarakatnya sebagai konsumen yang selalu menghasilkan sampah terutama plastik pada setiap pemakaian produk. Seiring dengan perkembangan teknologi kebutuhan plastik terus meningkat, plastik merupakan bahan anorganik buatan yang tersusun dari bahanbahan kimia yang sukar diuraikan sehingga berbahaya bagi lingkungan [1]. Sampah tersebut menjadi permasalahan lingkungan karena kuantitas maupun tingkat bahayanya mengganggu kelangsungan makhluk hidup. Oleh karena itu dengan mengubah sampah plastik menjadi barang yang dapat digunakan kembali dapat membantu mengurangi pencemaran lingkungan [2].

Kreativitas pemanfaatan sampah plastik menjadi kerajinan tangan adalah solusi yang cukup baik untuk mengubah sampah plastik menjadi menjadi barang yang berguna kembali, bahkan memiliki nilai jual serta dapat dikreasikan menjadi barang yang mempunyai nilai estetika. Kreativitas dalam diri seseorang 
dapat ditumbuhakan melalui banyak cara, salah satunya yaitu dengan membuat kerajinan tangan. Sampah plastik dapat dibuat kerajinan tangan seperti tas belanja, hiasan kamar, dompet, lampu hias, tempat pensil, keranjang, dan lain lain.

Penggunaan plastik dalam kehidupan manusia semakin lama semakin meningkat. Peningkatan pemanfaatan plastik ini terjadi karena plastik bersifat ringan, praktis, ekonomis dan dapat menggantikan fungsi dari barangbarang lain. Sifat praktis dan ekonomis ini menyebabkan plastik sering dijadikan barang sekali pakai, sehingga semakin banyaknya penggunaan perlengkapan dari bahan plastik tersebut, menyebabkan semakin banyak pula sampah-sampah plastik. Hal inilah yang menyebabkan jumlah sampah plastik meningkat terus menerus dan menyebabkan masalah lingkungan yang serius. Salah satu faktor yang menyebabkan rusaknya lingkungan hidup yang sampai saat ini masih tetap menjadi masalah yang belum terpecahkan secara tuntas besar bagi bangsa Indonesia adalah faktor pembuangan sampah plastik [3]. Perlu diketahui, diperlukan waktu puluhan bahkan ratusan tahun untuk sampah bekas plastik itu agar benar-benar terurai secara alamiah. Namun yang menjadi persoalan adalah dampak negatif sampah plastik ternyata sebesar fungsinya juga Oleh karena itu, jika sampah-sampah tersebut dibiarkan begitu saja akan menimbulkan bahaya yang sangat besar. kemudian menjualnya ke pengumpul plastik dan selanjutnya pengumpul akan mengirimkan dan menjual sampah plastik tersebut ke pabrik daur ulang di luar kota untuk diolah kembali menjadi bahan baku plastik.

\section{Permasalahan Mitra}

Permasalahan sampah menjadi problema klasik yang selalu dihadapi oleh penduduk terutama di wilayah Srengseng Sawah Jagakarsa. Hal ini disebabkan kerena usaha mengurangi volume sampah lebih kecil dari pada laju produksinya. Sehingga keberadaan sampah semakin menumpuk di setiap penjuru lingkungan perkotaan. Dengan volume timbunan sampah berlebihan menyebabkan kegiatan pengangkutan dan mengolah di TPA diluar kapasatitas yang ada. Sebagai dampak langsung maupun tidak langsung bagi penduduk dilingkungan ini, khususnya yang berdekatan dengan lokasi penumpukan sampah.
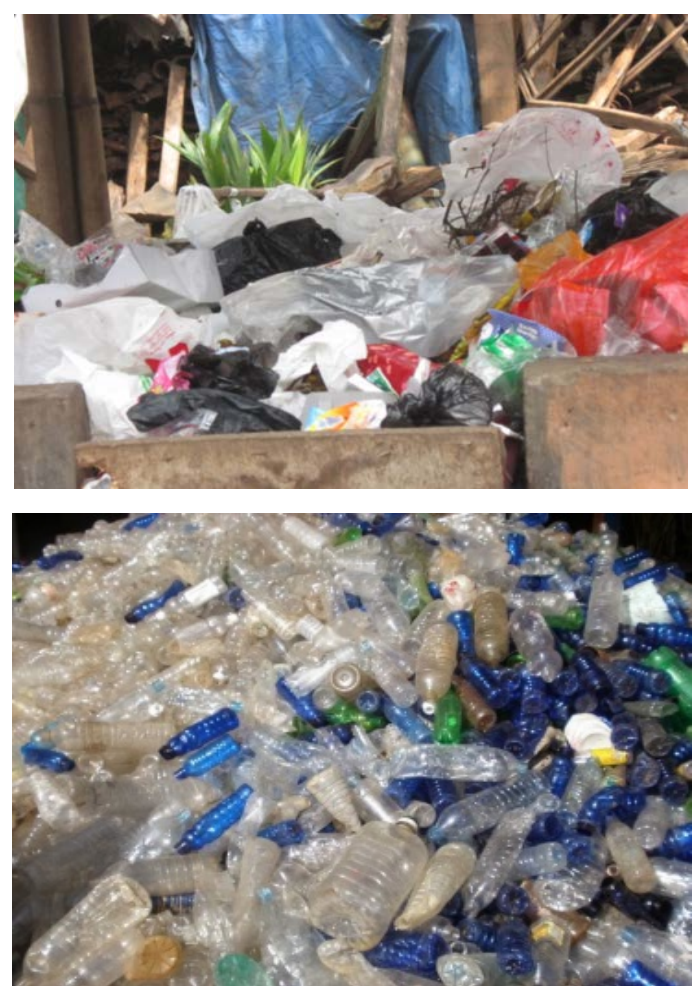

Gambar 1. Tumpukan Sampah di RT 01 RW 17 Srengseng Dawah

Tabel 1. Recovery Factor Komponen Sampah

\begin{tabular}{lc}
\multicolumn{1}{c}{ Komponen Sampah } & Recovery Factor (\%) \\
\hline Sampah mudah terurai & 80 \\
Sampah plastik & 50 \\
Sampah kertas & 40 \\
Sampah Logam & 80 \\
Sampah gelas kaca & 70 \\
\hline
\end{tabular}

Sumber: data penelitian

Dampak langsung adalah timbulnya berbagai penyakit menular, bau yang tidak enak, serta mengganggu kebersihan dan keindahan lingkungan. Adapun dampak tidak langsungnya adalah bahaya banjir yang disebabkan oleh terhambatnya arus air selokan dan sungai karena karena terhalang timbunan sampah. Permasalahan mitra dapat disimpulkan sebagai berikut :

1. Pengetahuan apa yang dapat diberikan kepada warga desa agar mau memanfaatkan sampah plastik yang ada di lingkungannya.

2. Pemanfaatan limbah plastik yang dapat meningkatkan pendapatan. 


\section{Target Luaran}

Adapun target dan luaran yang diharapkan dari pengelolaan sampah plastik yaitu sampah akan dipilah dengan benar sehingga memberi nilai tambah (manfaat) baik ekonomi maupun kesehatan. Sampah plastik dapat dikelompokan sesuai dengan jenis plastik yaitu plastik HD (kantong plastik), HDPE (botol shampo, sabun cair, pemutih, kecap, saus dll), LDPE (plastik kemasan teksturnya lembut, PS(steroform dan busa), PP (plastik transparan), PETE/PET (botol plastik air mineral,jus, dll dan plastik lain (plastik bening, pembungkus makanan, kemasan sachet, mie instan, kemasan minyak goreng, pewangi, dll). PVC (plastik yang susah didaur ulang spt plastik pembungkus atau botol). Bentuk pengabdian masyarakat dengan mengadakan kegiatan pelatihan kerajinan kreasi sebagai upaya pemanfaatan sampah plastik menjadi kerajinan tangan, luaran yang diharapkan.

Dapat secara terencana dilakukan pengukuran pengelolaan sampah yang benar.

1. Memotivasi masyarakat dalam pengelolaan sampah diharapkan mampu dan terampil dalam membuat kerajinan tangan berbahan dasar sampah plastik dan memiliki kreativitas dalam memanfaatkan sampah plastik.

2. Terbentuknya mekanisme dan menentukan orang untuk memantau dan mengevaluasi pengelolaan sampah berbasis masyarakat sehingga terciptanya peluang bisnis baru bagi masyarakat setempat sehingga dapat menurunkan angka kemiskinan dan meningkatkan kesejahteraan masyarakat

3. Menumbuhkan kesadaran masyarakat terhadap kebersihan lingkungan dengan memanfaatkan sampah plastik menjadi barang yang berguna kembali dan bernilai jual

4. Memberdayakan masyarakat khususnya ibuibu rumah tangga, pemuda pengannguran, dan anak-anak yang putus sekolah agar dapat mengembangkan kreativitasnya melalui pelatihan membuat kerajinan tangan yang bernilai jual juga meningkatkan penghasilan.

5. Menanamkan kepada masyarakat pentingnya berwirausaha sehingga dapat menciptakan peluang usaha melalui kreativitas dengan kreasi kerajinan tangan sampah plastik

6. Masyarakat lebih sadar akan kebersihan lingkungan sehingga dapat meminimalisir dampak negative pencemaran lingkungan

7. Terciptanya transfer pengetahuan kemajuan teknologi pengelolaam sampah antara civitas akademika Universitas Pancasila dengan warga dan mahasiswa.

\section{METODE PENELITIAN}

Metode yang digunakan dalam Program Pemanfaatan Limbah Plastik Sebagai Kerajian Tangan di Kelurahan Srengseng Sawah Jagakarsa Jakarta Selatan ini terbagi menjadi dua tahap, yaitu 1. Survey analisis situasi.2. Pelaksanan Penyuluhan dan Pelatihan yang terdiri dari 3 kegiatan yaitu Persiapan, Pelaksanaan Program dan Evaluasi

Kegiatan pelatihan pemanfaatan sampah plastik menjadi kerajinan tangan yang mempunyai nilai jual ini dilakukan berbasis pada masyarakat dimulai dengan kegiatan pemilahan sampah rumah tangga dimaksudkan untuk menghindari turunnya nilai barang yang masih dapat dimanfaatkan dan memperkecil jumlah dan komposisi sampah. Meskipun kegiatan pemilahan ini tidak secara langsung mengurangi timbulan sampah, namun dapat membantu proses pengurangan sampah pada pengolahan sampah selanjutnya. Kegiatan pemilahan sampah pada skala rumah tangga ini sangat mudah untuk dilakukan oleh ibu rumah tangga dan pembantu rumah tangga yang berperan dalam pelaku kebersihan di setiap rumah tangga. Kegiatan yang dilakukan adalah:

1. Mengadakan penyuluhan (sosialisasi) cara pengelolaan sampah plastik bagi masyarakat disekitarnya yang berjumlah lebih kurang 40 Warga terpilih, dibagi 2 kali pelatihan setiap kelompok terdiri dari 20 warga. Dengan memberikan penyuluhan atau sosialisasi tentang pengolahan sampah rumah tangga yang selanjutnya bisa diolah menjadi barang bermanfaat.

2. Pelaksanan Kegiatan pelatihan

a. Tahap Persiapan

Sebelum melakukan Program

Pengabdian Masyarakat ini, pelaksana 
kegiatan melakukan konsultasi dengan dosen pendamping secara intensif, melakukan perijinan ke kelurahan mengenai pelaksanaan kegiatan. Kemudian melakukan observasi terhadap masyarakat sasaran dan melakukan koordinasi kepada pihak yang bersangkutan. Melakukan persiapan tempat, alat dan bahan sekaligus materi tentang wirausaha dan pembuatan kerajinan tangan berbahan baku sampah plastik.

b. Tahap Pelaksanaan Kegiatan

Pelatihan kreasi dalam upaya pemanfaatan sampah plastik menjadi kerajinan tangan ini akan dilaksanan melalui beberapa tahap:

a. Sosialisasi Program

Sosialisasi program dilaksanakan setelah tahap persiapan selesai yaitu dengan melakukan pertemuan dengan calon peserta yang mengikuti kelas kreasi ini dan mensosialisasikan tentang program yang akan di laksanakan.

b. Penyampaian Materi

Pada tahap ini peserta akan diberikan materi seputar kewirausahaan dan cara membuat kerajinan tangan dengan berbahan baku sampah plastik. Penyampaian materi menggunakan media power point. Materi diberikan oleh mahasiswa yang terlibat dalam program ini.

c. Pelatihan Kreasi

Pelatihan kreasi yaitu praktek pembuatan berbagai macam kerajinan tangan yang berbahan dasar sampah plastik dengan alat dan bahan yang sudah disediakan. Praktek di damping oleh mahasiswa yang bersangkutan. Kerajinan tangan tersebut berupa tas, dompet, dan tempat untuk menyimpan barang-barang kecil.

d. Pemanfaatan Hasil Kerajinan Tangan

Hasil dari kelas kreasi yang berupa kerajinan tangan seperti tas belanja, dompet, dan lain-lain kemudian di jual kepada masyarakat umum seperti di pasar, toko-toko dan di tempat umum oleh peserta kelas kreasi sehingga bisa menciptakan peluang usaha bagi mereka untuk meningkatkan penghasilan serta melatih berwirausaha.

e. Evaluasi

Evaluasi dilakukan setelah semua tahap diatas telah terlaksana yaitu dengan meminta kritik dan saran melalui kuesioner pada peserta kelas kreasi mengenai pelaksanaan program.

\section{HASIL DAN PEMBAHASAN}

Analisis Situasi Kelurahan Srengseng Sawah

Limbah plastik merupakan masalah serius bagi pencemaran lingkungan khususnya bagi pencemaran tanah.Bahan plastik merupakan bahan organik yang tidak bisa terurai oleh bakteri. Dan alangkah baiknyajika limbah plastik tersebut dapat digunakan lagi dengan cara mendaur ulang dan dijadikanproduk baru. Upaya pengelolaan daur ulang sampah plastik telah banyak dilakukan oleh pemerintah, seperti dengan menyediakan tempat sampah yang sudah dipecah menjadi beberapa kategori sampah (sampah basah dan sampah kering). Akan tetapi strategi ini masih belum memberikan hasil yang signifikan dalam reduksi jumlah sampah plastik. Dengan kata lain,manajemen yang ada saat ini belum sepenuhnya berjalan efektif. Masih banyak masyarakat yang membuang sampah tidak berdasarkan kategori sampah.

Peningkatan pemahaman kepada masyarakat perlu dilakukan baik dengan sosialisasi secara langsung maupun tidak langsung. Seperti yang diungkapkan oleh Vesilind yang menyatakan bahwa dalam implementasi sebuah manajemen/pengelolaan sampah dalam sebuah komunitas, hal pertama yang dilakukan adalah dengan melakukan reduksi sampah langsung pada sumber penghasil sampah [3]. Dibutuhkan sebuah cara efektif agar dalam aktivitas ini, sampah plastik yang terkumpul sudah terpisah berdasarkan kategori jenis plastik, sehingga proses daur 
ulang di tingkat selanjutnya dapat dilakukan lebih efisien. Pengelolaan daur ulang sampah plastik yang ergonomis dan terintegrasi dengan baik akan dapat membantu kegiatan atau program strategis dalam upaya pengurangan jumlah sampah plastik yang efektif. Dalam proses suatu sistem ada 6 aspek yang perlu diperhatikan yaitu secara teknis, ekonomis, ergonomis, sosio-kultural, bisa dipertanggungjawabkan, hemat energi, dan turut melestarikan lingkungan [6]. Dengan memperhatikan keenam aspek atau kriteria inilah yang akan digunakan dalam penyusunan manajemen/pengelolaan daur ulang sampah plastik ini.

Dalam pelaksnaan kegiatan pengabdian masyarakat ini akan dilakukan sosialiasi dan pemahaman tentang pemanfaatan limbah plastik dan kemudian dilakukan pelatihan pembuatan kerajinan tangan yang berasal dari limbah plastik. Strategi manajemen/pengelolaan daur ulang sampah plastik yang efektif dengan melibatkan masyarakat (sumber penghasil sampah) secara langsung dan lembaga-lembaga informal daur ulang yang terkait, disertai dengan pemilihan teknologi dan fasilitas yang efisien dan ergonomis guna meningkatkan pemberdayaan masyarakat. Dengan pelatihan kerajinan limbah plastik diharapkan dapat meningkatkan pendapatan rumah tangga dengan pemberdayaan masyarakat dan diharapkan dapat menekan jumlah sampah plastik.

\section{Survey Responden}

Indentifikasi permasalahan dilakukan dengan menyebarkan sejumlah kuisioner terhadap 75 responden untuk mengetahui tingkat kesadaran dan pengetahuan masyarakat mengenai sampah dan sampah plastik khususnya. Berdasarkan hasil wawancara secara acak terhadap 75 responden, 45\% menyatakann mengetahui perbedaan antara sampah basah dan sampah kering dan sisanya yaitu sebesar 55\% menyatakan masih bingung atau belum mengetahui perbedaan sampah basah dan sampah kering.

Untuk jenis sampah plastik, pemulung, lapak maupun bandar membagi menjadi 8 kategori. Yaitu :
1. Plastik putih/bening.
2. Plastik botol.
5. Plastik bak.
6. Plastik atom.

3. Plastik gelas

4. Plastik PE-putih.

7. Plastik campur.

8. Plastik tas kresek.

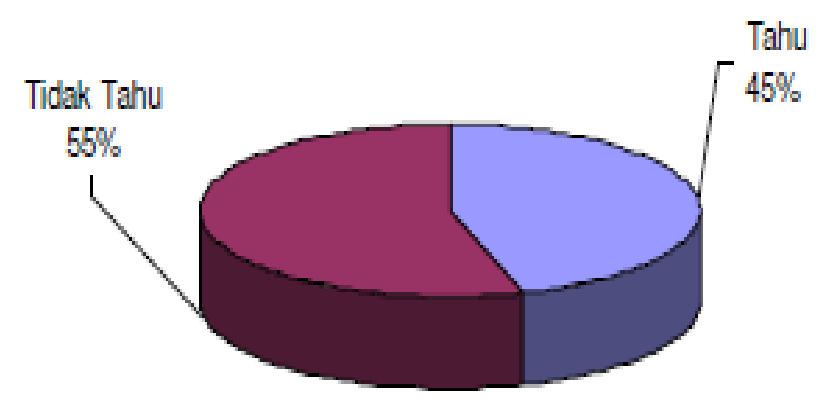

Gambar 2. Prosentase Wawancara Pengertian Sampah

\section{Identifikasi Permasalahan Pengelolaan Sampah Plastik}

Secara umum permasalahan yang dihadapi oleh para pelaku daur ulang sampah plastik terletak pada kesulitan dalam pemilahan sampah plastik berdasarkan jenisnya. Hal ini lebih banyak disebabkan oleh tercampurnya segala jenis sampah mulai dari sumber. Sampah basah maupun sampah kering tercampur jadi satu dan ditimbun begitu saja sampai diambill oleh petugas kebersihan. Selain itu percampuran antar jenis sampah plastik juga terjadi akibat kegiatan pemulung/perangkas ketika mengambil barang bekas yang masih bernilai di timbunan sampah. Jumlah sampah kota yang dihasilkan di Srengseng Sawah adalah sebesar $700 \mathrm{~m}^{3} /$ hari. Data kelurahan Srengseng sawah dimana dari total timbulan sampah yaitu $700 \mathrm{~m}^{3} /$ hari, sekitar $79,21 \%$ berasal dari rumah tangga. Dan kurang lebih 10,09\% merupakan sampah

\section{Pelaksanan Penyuluhan dan Pelatihan}

1. Persiapan

a. Persiapan Bahan dan Alat

Pada tahap ini yang dilakukan terlebih dahulu adalah menyiapkan akan tersedianya bahan dan alat. Bahan dan alat yang digunakan antara lain:
a). Bungkus Kopi
f). Lem
b). Kain Fanel
g). Benang
c). Resletting
d). Pernak-pernik
e). Gunting
h). Jarum
i). Bungkus makanan ringan



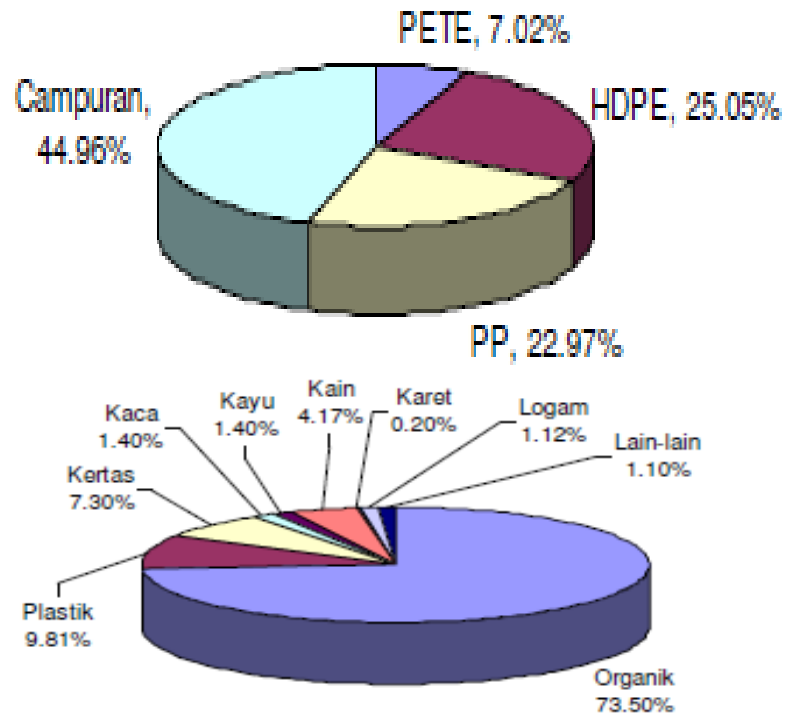

Gambar 3. Komposisi Sampah Plastik Produk Kemasan di Srengseng Sawah

b. Persiapan Tempat

Proses kegiatan ini akan di Laksanakan di RW 19 dan RW 17 Kelurahan Srengseng Sawah Jagakarsa Jakarta Selatan

2. Pelaksanaan program Penyuluhan Pengelolaan sampah plastik

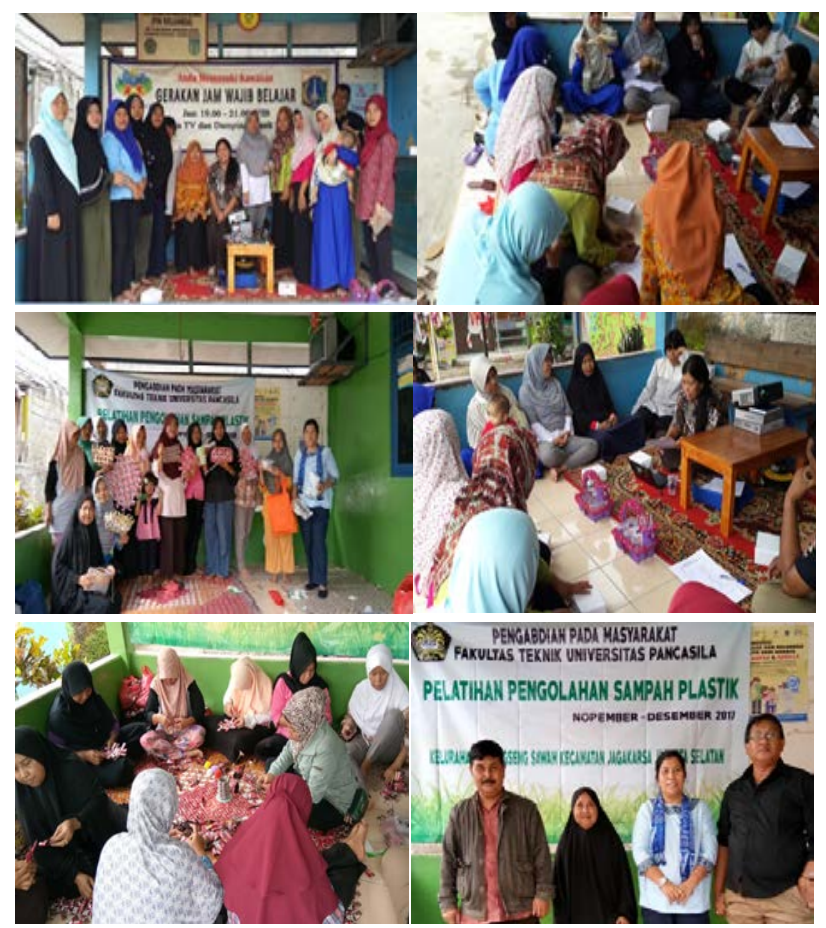

Gambar 4. Foto Kegiatan Pengelolaan Sampah Plastik di Kelurahan Srengseng Sawah

\section{Pelatihan untuk Pemilahan Sampah Plastik}

Dengan melakukan penjelasan tentang jenis plastik memiliki sistem pengolaha senediri. Untuk plastik jenis LDPE, HDPE, PET, PVC, PS, dan PP Ada beberapa tahap yang dilakukan dalam mendaur ulang plastik, yaitu:

1. Bersihkan plastik dari kontaminer seperti kertas, ataupun tipe plastik yang lain (biasanya berasal dari label plastik atau sisa isi yang masih melekat). Untuk membersihkan bisa menggunakan cutter maupun dicuci sampai benar-benar bersih dari kontaminer.

2. Pipihkan plastik (bila berongga seperti botol) dengan cara menginjaknya atau menggunakan mesin pres.

3. Masukkan ke dalam mesin perajang plastik.

4. Pilah kembali serpihan plastik untuk membedakan tiap tipe plastik. Media yang digunakan adalah air atau minyak goreng. Berikut identifikasi yang dapat dilakukan untuk membantu membedakan antar tipe plastik:

5. Plastik yang telah dibedakan tipenya (tenggelam dan mengapung), dipisahkan untuk diproses sesuai dengan tipenya. Serpihan akan dimasukkan ke dalam mesin peleleh (melting). Temperatur yang digunakan untuk masing-masing tipe plastik dapat dilihat pada tabel di bawah ini

Tabel 2. Media Pemilahan Plastik

\begin{tabular}{clll}
\hline No & Tipe Plastik & Media Air & $\begin{array}{c}\text { Media } \\
\text { Minyak }\end{array}$ \\
\hline 1 & PET & Terapung & Terapung \\
2 & HDPE & Terapung & Terapung \\
3 & PVC & Tenggelam & Tenggelam \\
4 & LDPE & Terapung & Terapung \\
5 & PP & Tenggelam & Tenggelam \\
6 & PS & Terapung & Terapung \\
7 & Multilayer & Terapung & Terapung \\
\hline
\end{tabular}


Tabel 3. Temperatur Leleh Plastik

\begin{tabular}{|c|c|c|}
\hline No & Tipe Plastik & $\begin{array}{l}\text { Temperatur } \\
\text { Leleh }\end{array}$ \\
\hline 1 & $\begin{array}{l}\text { PET (Polyethylene } \\
\text { Terephtalate) }\end{array}$ & $700 C-800 C$ \\
\hline 2 & $\begin{array}{l}\text { HDPE (High Density } \\
\text { Polyethylene) }\end{array}$ & $700 C-800 C$ \\
\hline 3 & PVC (Polyvinyl Chloride) & $700 C-1000 C$ \\
\hline 4 & $\begin{array}{l}\text { LDPE (Low Density } \\
\text { Polyethylene) }\end{array}$ & $700 C-800 C$ \\
\hline 5 & PP (Polypropylene) & $1600 C-1700 C$ \\
\hline 6 & PS (Polystyrene) & $800 C-950 C$ \\
\hline 7 & Multilayer & Pengecoran \\
\hline
\end{tabular}

\section{Hasil Krasi Pelatihan}

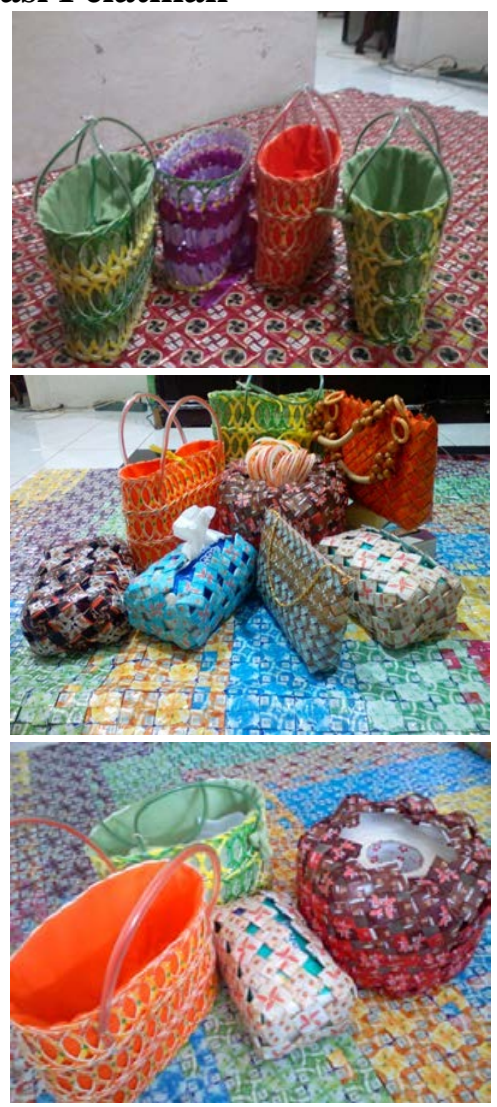

Gambar 5. Hasil Kreasi Sampah Plastik di Kelurahan Srengseng Sawah

\section{KESIMPULAN}

Barang-barang bekas khususnya limbah plastik dapat membuka lapangan kerja baru. Hal ini dibuktikan dengan bungkus kopi dapat dibuat menjadi tas yang menarik dan unik tentunya. Proses pembuatannya tidak memerlukan banyak modal besar karena hanya memanfaatkan barang bekas. Cara pembuatannya hanya tinggal menganyam potongan-potongan bungkus kopi.Dalam pelaksanaan kegiatan dapat dengan menggunakan metode persiapan, pelaksanaan program pengabdian dan evaluasi. Proses pengabdian dapat dengan cara terjun langsung ke lingkungan untuk memperkenalkan karya ini. Kegiatan pengabdian ini cukup baik untuk dilaksanakan, karena dapat meminimalisir pencemaran lingkungan oleh limbah plastic dan mengembangkan inovasi masyarakat.

\section{DAFTAR PUSTAKA}

[1] Artiningsih. 2008. Peran Serta Masyarakat dalam Pengelolaan Sampah Rumah Tangga (Studi Kasus di Sampingan dan Jomblang, Kota Semarang). Program Magister Lingkungan Universitas Dionegoro. Semarang

[2] Badan Pusat Statistik Provinsi DKI Jakarta. 2011. „Banyaknya Penduduk Berdasarkan Hasil Registrasi Menurut Wilayah di Provinsi DKI Jakartae . http://jakarta.bps.go.id/ind

[3] Cahyani GD. 2009.Analisis Faktor-Faktor yang Mempengaruhi Produksi Sampah dan Kelayakan Finansial Usaha Pengelolaan Sampah Rumah Tangga (Studi Kasus di Perumahan Cipinang Elok, Jakarta Timur).Departemen Ekonomi Sumberdaya dan Lingkungan Institut Pertanian Bogor. Bogor

[4] Dinas Kebersihan Provinsi DKI Jakarta 2005. „Solid Waste Management for Jakarta: Master Plan Review and Program Development". TA-Package No. DKI 311. Dinas Kebersihan Provinsi DKI Jakarta. Jakarta

[5] Dinas Kebersihan Provinsi DKI Jakarta 2011.,Laporan Tahunan Kebersihan DKI Jakarta Tahun 2010"e. Dinas Kebersihan Provinsi DKI Jakarta. Jakarta

[6] Manuaba, A. 2004. Holistic EErgonomics Approach is a Must in Automation to Attain Humane, Competitive, Sustain Work Processes and Products. Denpasar: PHd program of Ergonomics and Sports Physiology, School of Medicine, Udayana University. 